\title{
Folic acid and diseases - supplement it or not?
}

\author{
SIAW-CheOK LIEW ${ }^{1 *}$ \\ ${ }^{1}$ Dr. - Lecturer at Clinical Skills and Simulation Centre, International Medical University, Kuala Lumpur, Malaysia
}

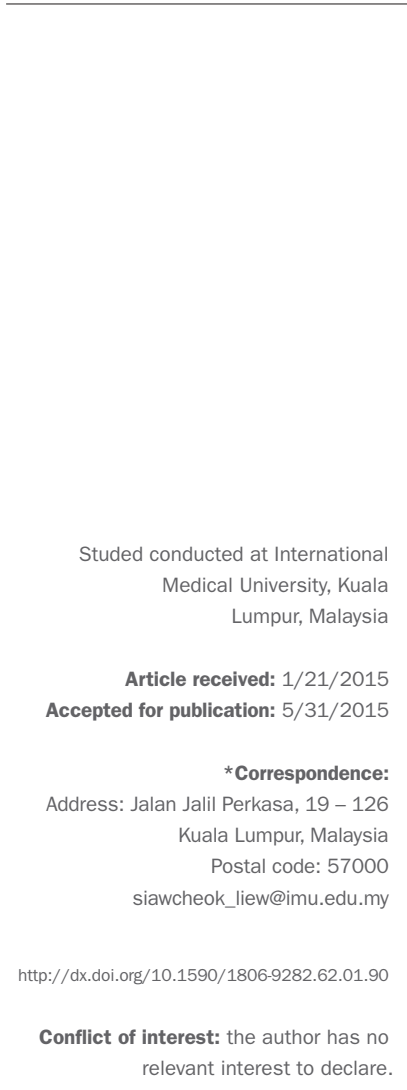

\section{INTRODUCTION}

The origin of folate is the Latin word folium which means leaf. Folic acid, also known as vitamin B9, is a form of synthetically-produced water soluble vitamin found in fortified food and supplements. Folate is naturally derived from food, particularly from dark green leafy vegetables. ${ }^{1} \mathrm{Hu}-$ mans are not able to synthesize folate de novo and, therefore, the daily requirements of folate are met with consumption of food rich in this vitamin. ${ }^{2}$ Folate and the biologically active folic acid, which is converted to dihydrofolic acid in the liver, are essential in meeting the requirements of the function of the human body. Folate is used to synthesize, repair and methylate Deoxyribonucleic acid (DNA); ${ }^{2}$ therefore it is especially important in pregnancy and childhood for continuous cell division and growth. ${ }^{1}$ Folate deficiency can cause many unwanted health problems, although severe deficiency is only seen months after the depletion of the dietary intake when the folate storage is exhausted. Common unwanted health problems due to folate deficiency is macrocytic anemia, weakness and confusion, memory def- icits, shortness of breath, peripheral neuropathy, pregnancy complications and depression. ${ }^{2,3}$ Hyperhomocysteinemia and cancer development due to impaired DNA synthesis and repair could be the long-term complications of folate deficiencies. Contradictory findings were found regarding the supplementation of folic acid and its medicinal effects for the treatment of many diseases globally. The rapid expansion on the research pertaining to the benefits of folic acid, which yielded contradictory findings, leads to a need of frequent updates on this topic. The most updated information on the associations of the serum folic acid status and some of the common diseases found globally are discussed in this review.

\section{Methods}

Most articles included in this review were published between 2000 and 2014, and focused on recent, updated evidence-based reports and meta-analyses on the associations of the serum folate/folic acid and the various diseases found globally. 


\section{FoLIC ACID}

Background

Folic acid is also known as folate, folacin, vitamin B9, Vitamin M, Folvite, Acifolic, Folcidin, and scientifically as pteroylglutamic acid. ${ }^{4}$ It was first found by Lucy Wills, a consultant pathologist at the Royal Free Hospital in London through her work, which resulted in correcting macrocytic anemia of pregnancy in female textile workers in Bombay. ${ }^{5,6}$ In 1941, folic acid was first isolated from spinach hence its name folium (leaf), ${ }^{7}$ being subsequently synthesized in pure crystalline form in 1943 by Stokstad and in 1945 by Angier. ${ }^{8}$ Synthesized folic acid, therefore, differs structurally from folate as it possesses additional glutamate residues (polyglutamates), reduction to the di- or tetra-hydroforms and the addition of a carbon unit, i.e. the methyl (-CH3), formyl-CHO, methylene $=\mathrm{CH} 2$, methenyl $=\mathrm{CH} 4$, which are attached to either the N5 or N10 nitrogen atoms. ${ }^{5}$ Since its synthesis, folic acid has been used for the treatment of megaloblastic anemia. ${ }^{9,10}$

\section{Sources}

Although the terms folic acid and folate are used interchangeably, the metabolic effects can be slightly different. Folic acid which is found in supplements and fortified food is the synthetic form of folate. Folate is found naturally, mainly in plants. ${ }^{1}$ Folate is found in plants and vegetables such as dark leafy greens, broccoli, asparagus, citrus fruits (oranges, grapefruits, strawberries), beans, avocado, peas and lentils, okra, Brussels sprouts, nuts and seeds, cauliflowers, beets, corn, celery, carrots and squash. ${ }^{11}$ Folate can also be found in meat product including chicken, turkey, lamb, beef and pork liver. Folic acid, on the other hand, can be found in fortified foods, such as cereal, pasta, flour, grains and bread. Folic acid supplements are sold over the counter in tablet or powder forms. ${ }^{11}$ The daily recommended allowance (RDA) of folic acid in the United States is $400 \mathrm{mcg} /$ day for teenagers and adults, $500 \mathrm{mcg} /$ day for breast-feeding women and $600 \mathrm{mcg} /$ day in pregnancy. ${ }^{1}$

\section{Chemical structure and properties of folic acid}

Folic acid or folate has a molecular formula of $\mathrm{C} 19 \mathrm{H}-$ -19N7O6 and a molecular weight of $441.39746 \mathrm{~g} / \mathrm{mol}^{4}$ Folic acid is a yellow or yellowish-orange crystalline powder, a B vitamin which contains pteridine linked to paraaminobenzoic acid by a methylene bridge and is linked to glutamic acid by a peptide linkage. It is very slightly soluble in water and in alkaline hydroxides and carbonates but insoluble in alcohol. ${ }^{4}$
Metabolism of folic acid and folate

The estimated body content of folate is about $10 \mathrm{mg}$ to $30 \mathrm{mg}$. The normal serum level of total folate is about 5 to $15 \mathrm{ng} / \mathrm{mL}$, while 16 to $21 \mathrm{ng} / \mathrm{mL}$ is the normal cerebrospinal fluid level. The normal levels of folate in erythrocytes range from 175 to $316 \mathrm{ng} / \mathrm{mL}$. A higher percentage of folate is stored in the liver, some in the blood and tissues. Levels below $5 \mathrm{ng} / \mathrm{mL}$ of serum folate indicate folate deficiency and megaloblastic anemia was seen at a level below $2 \mathrm{ng} / \mathrm{mL}$. ${ }^{4,12}$ Food folate in the intestines after consumption are primarily hydrolyzed to monoglutamate form and absorbed via active transport across the small intestinal mucosa. Folic acid when consumed as a supplement is absorbed rapidly, primarily in the proximal portion of the small intestine via passive diffusion. ${ }^{13}$ Monoglutamate is then reduced to tetrahydrofolate (THF) in the liver and converted to either the meth$\mathrm{yl}$ or the formyl forms before entering the bloodstream. Folate is commonly found in the bloodstream as 5-methyl-tetrahydrofolate. ${ }^{14,15}$ Erythrocyte folate concentration is sometimes used to measure the long term intake of folate especially in those with variable folate intake and in those who are ill, where a value above $140 \mathrm{ng} / \mathrm{mL}$ is considered adequate. ${ }^{15}$ Hyperhomocysteinemia or high plasma homocysteine is defined as a level higher than 16 micromoles/L although lower values of 12 to 14 micromoles/L have also been used 13 and is an indicator for the poor conversion of homocysteine to methionine due to a defect in 5-methyl-tetrahydrofolate. ${ }^{16}$ The metabolic products of folic acid normally appear in the urine 6 hours after ingestion and complete excretion is generally within 24 hours with a smaller residue found in the feces. Folic acid is also excreted in breast milk. ${ }^{4}$ The folic acid metabolism is shown in Figure 1.

\section{THE FUNCTION OF FOLIC ACID METABOLISM} DNA synthesis and repair

Folic acid metabolism, which generates nucleic acid building blocks, is important in the synthesis and repair of DNA. Deoxyuridine monophosphate (dUMP) through addition of a methyl group by the enzyme thymidylate synthase results in the de novo synthesis of deoxythymidine monophosphate (dTMP) with subsequent phosphorylation to deoxynucleotide triphosphate (dNTP) and thymidine triphosphate (dTTP). Thymidine triphosphate (dTTP) is one of the four deoxyribonucleic acids essential for DNA synthesis and repair. Folate deficiency will block the conversion of dUMP to dTMP leading to the excess of deoxyuridine triphosphate (dUTP). As DNA 


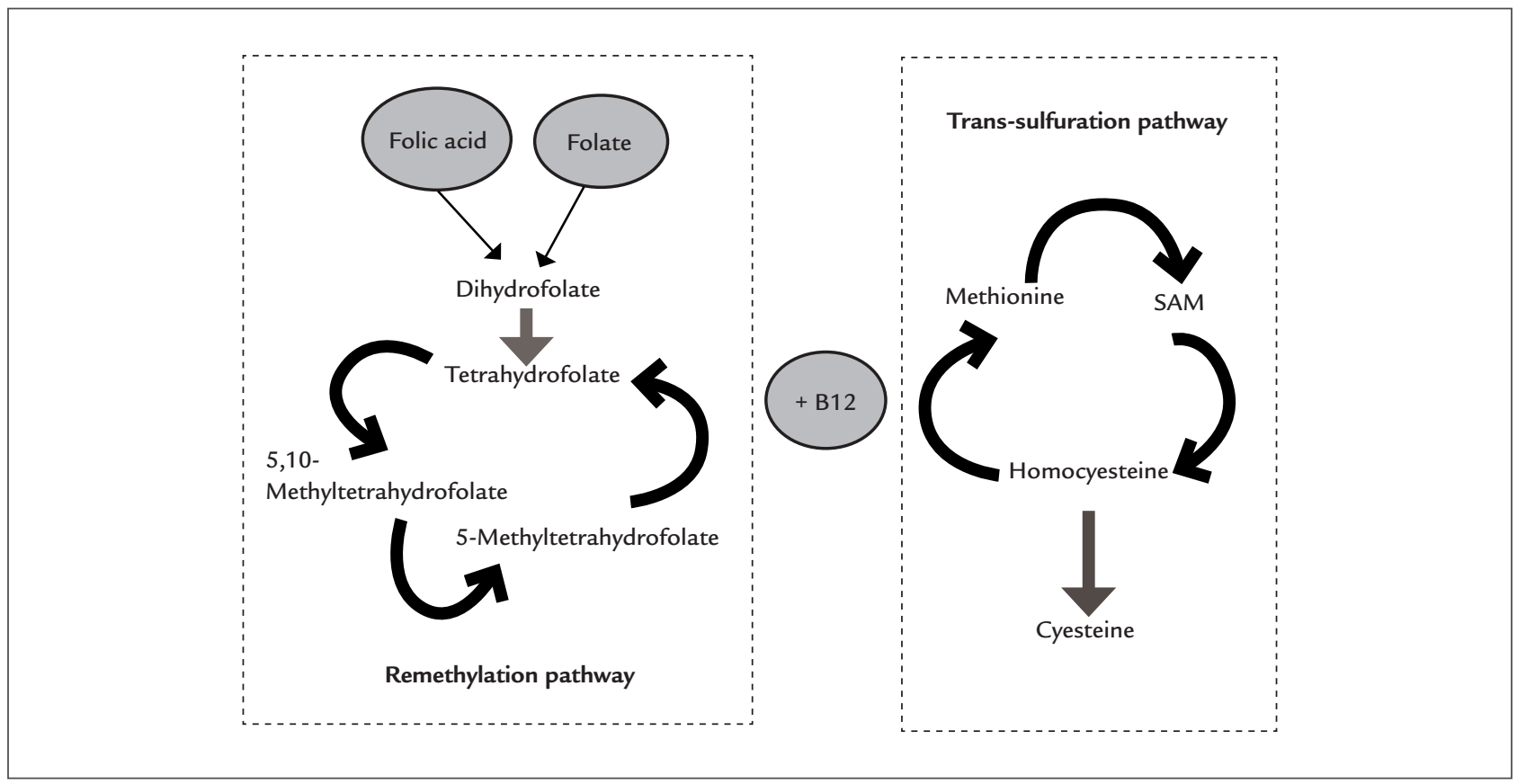

FIGURE 1 The folic acid metabolism.

polymerases are unable to distinguish between dUTP and DTTP, there is a chance of the mis-incorporation of the uracil into the DNA in place of thymidine. With increasing depletion of thymidine due to folate deficiency, the continual mis-incorporation of uracil into DNA will eventually lead to 'futile' or 'catastrophic' DNA repair. DNA destabilization may lead to chromosome aberrations and potentially malignant transformation. ${ }^{17-21}$

\section{Conversion of homocysteine to methionine}

A second important folate metabolic reaction is the conversion of homocysteine to methionine by the action of 5 -methyltetrahydrofolate (5-methyl-THF). Some of this regenerated methionine is subsequently converted to the enzyme methionine adenosyl transferase to produce its active form, S-adenosylmethionine (SAM). S-adenosylmethionine (SAM) participates in numerous types of methylation reactions of molecules such as lipids and peptides. SAM is the major methyl contributor in the methylation of cytosine to DNA. In folate deficiency, the reduction of methylation of cytosine in DNA might result in pro-oncogene expression and potential malignancy transformation. ${ }^{20-22}$

\section{Cell replication and survival}

Folate depletion and subsequent reduction of DNA synthesis and DNA methylation are toxic to both normal and malignant cells because folate metabolism is funda- mental to both cancerous and normal cells. Folate deficiency due to insufficient thymidine can result in DNA damage and can also result in hypomethylation of DNA due to reduced levels of S-adenosylmethionine. Ironically, due to the importance of folate metabolism for cell replication and survival, the inhibition of folic acid metabolism has been shown as a successful mechanism for the elimination of malignant cells and has therefore been trialed as antitumor therapeutics. Aminopterin, is a folic acid analog (4-aminofolic acid) that inhibits dihydrofolate reductase, thus, preventing the reduction of folic acid and dihydrofolic acid to tetrahydrofolate (THF). Methotrexate (MTX) is another analog of folic acid that is used to directly inhibit dihydrofolate reductase and to inhibit thymidylate synthase. Other folate structural analogs used in cancer chemotherapy include trimetrexate, permetrexed, and raltitrexed. ${ }^{23,24}$

\section{FOLIC ACID AND DISEASES}

There were many studies looking at the effects of folic acid and diseases, therefore yielding an exhaustive list of publications in this area. However, the studies on the association of the folic acid and diseases have resulted in many contradictory findings. The diseases discussed in this review were mainly based on the reported studies and the meta-analyses. Table 1 summarizes the reported studies and meta-analyses on the association of folic acid and diseases discussed in this article. 
TABLE 1 Folic acid and diseases.

Diseases research reports

Hyperhomocysteinaemia: Stanger et al., 2004; Welsch et al., 1997;

Homocysteine Lowering Trialists' Collaboration, 2005; Homocysteine Lowering Trialists' Collaboratio, 1998.

Coronary artery disease: Qin et al., 2012; Wang et al., 2012; de Bree et al, 2007; Miller et al., 2010; Zhou et al., 2011; Bazzano et al., 2006.

Hypertension: McRae, 2009; Cagnacci et al., 2014; Béchir et al., 2005; Forman et al., 2005

Stroke: Yang et al., 2012; Wang et al., 2007; Huo et al., 2012; Lee et al., 2010.

Diabetes: Sudchada et al., 2012; Title et al., 2006; Xu et al., 2012; Schneider et al., 2014; Fotiou et al., 2014; Yilmaz et al., 2013; Negrão et al., 2014; Parker et al., 2013.

Pregnancy: Imdad et al., 2011; Grosse and Collins ,2007; Peake et al., 2013; Charles et al., 2005; Lassi et al., 2013; Fekete et al., 2012; De-Regil et al., 2010; Jian et al., 2009.

\section{Cancers:}

Prostate: Wien et al., 2012; Collin, 2013; Rycyna, 2013; Jeffrey et al., 2014; Tio et al., 2014.

Colorectal: Paspatis et al., 1995; Paspatis et al., 1994; Carroll et al., 2010; Figueiredo et al., 2011; Castillo-Lancellotti et al., 2012; Keum and Giovannucci, 2014; Kennedy et al., 2011; Ryan et al., 2001; Giovannucci et al., 1995; Takata et al., 2014.

Pancreatic: Bao et al., 2011; Oaks et al., 2011; Skinner et al., 2004; Lin et al., 2013; Keszei et al., 2009; Stolzenberg-Solomon et al., 2001; Larsson et al., 2006.

Breast: Larsson et al., 2007; Stolzenberg-Solomon et al., 2006; Chen e tal., 2014; Zhang et al., 2014; Deghan Manshadi et al., 2014. Leukaemia: Ajrouche et al., 2014; Lupo et al., 2014; Jain et al., 2014. Lung: Dai et al., 2013; Shen et al., 2003; Bandera et al., 1997; Slatore et al., 2008; Marchand et al., 2002; Neuhouser et al., 2003; Yang et al., 2013.

Kidney diseases: Qin et al., 2011; Jardine et al., 2012.

Neurology: Schneider et al., 2006; Castillo Lancellotti et al., 2012.

Childhood asthma: Zetstra-van der Woude et al., 2014; Crider et al., 2013.

\section{Hyperhomocysteinemia}

Methylenetetrahydrofolate reductase (MTHFR) plays an important role as an enzyme in folate metabolism. The mutation of the MTHFR gene at position $677 \mathrm{CT}$, which converts alanine to valine, results in decreased enzyme activity. A significant reduction of $65 \%$ enzymatic activity in the homozygous MTHFR TT genotypes and 30\% reduction in the heterozygous $\mathrm{CT}$ genotypes has been associated with elevated homocysteine levels, DNA hypomethylation and genomic instability. ${ }^{25,26}$ Hyperhomocysteinemia or high plasma homocysteine level has been reported as a risk factor for atherosclerosis and coronary artery diseases. ${ }^{27}$ When compared to healthy individuals, forty percent of patients with coronary artery disease, cerebral or peripheral artery disease were found to have high plasma homocysteine level. ${ }^{28}$ Homocysteine was postulated to cause atherogenesis and thrombogenesis leading to substantial fibrosis and muscle cell hyperplasia although the exact mechanism is still unknown. ${ }^{28}$ Observational studies also suggested that hyperhomocysteinemia is an independent risk factor for cardiovascular related diseases. A maximal reduction in plasma homocysteine concentrations could be achieved with a minimal dose of $0.8 \mathrm{mg} /$ day of folic acid. ${ }^{29} \mathrm{~A}$ reduction of a quarter to a third in blood homocysteine concentrations in Western populations was seen with the supplementations of both $0.5-5 \mathrm{mg} /$ day of folic acid and about $0.5 \mathrm{mg} /$ day of vitamin B12. However, it was suggested that more evidence of its effect in the reduction of the risk factor of vascular disease due to the lowering of blood homocysteine concentrations could be determined with larger-scaled randomized trials of such regimens in high risked population. ${ }^{30}$

\section{Coronary artery disease}

A meta-analysis by Qin et al. indicated the effectiveness of folic acid supplementation in the reduction on cardiovascular disease (CVD) risk measured by the progression of carotid intima-media thickness (CIMT). ${ }^{31}$ A meta-analysis by Wang et al. suggested that coronary heart disease risk was inversely related to dietary folate supplementation and blood folate level. ${ }^{32}$ Similarly, a meta-analysis by de Bree et al. suggested that the risk of cardiovascular disease was reduced with high folic acid supplementation due to the improvement on endothelial function. ${ }^{33}$ However, Miller et al. commented that although folic acid was suggested from previous studies to have homocysteinelowering effect and might be beneficial in the prevention of CVD, folic acid on the contrary might also promote progression of atherosclerosis because it also stimulates cell proliferation. Subsequently, a meta-analysis by Miller et al. reported that folic acid supplementation did not have any effect on CVD or stroke. ${ }^{34}$ Likewise, Zhou et al. reported in their meta-analysis that folic acid supplementation had no effect on major cardiovascular events, stroke, myocardial infarction, acute coronary syndrome and vascular death compared to placebo. ${ }^{35}$ Similarly, Bazzano et al. also reported no reduction in the risk of cardiovascular diseases or mortality rate in those with history of vascular disease with folic acid supplementation. Therefore, it was recommended that trials with large sample sizes 
will be needed in the future, in order to answer this important clinical and public health question. ${ }^{36}$

\section{Hypertension}

McRae, based on a meta-analysis, reported that in order to lower systolic blood pressure attained through improved endothelial function, folic acid supplementation of $5 \mathrm{mg} /$ day for a minimum of 6 weeks is be required. ${ }^{37} \mathrm{~A}$ double blinded, placebo-controlled study on postmenopausal women who received 5-MTHF (folate/prefolic) yielded a positive correlation between the administration of folate and the reduction of blood pressure in this group of patients. ${ }^{38}$ Folic acid $(5 \mathrm{mg})$ has been found to improve cardiac and vascular sympathetic baroreceptor sensitivity in twenty-one hypertensive male patients in a study with matching placebo. The results also suggested improved vagal control and enhanced baroreceptor modulation of sympathetic vasomotor tone; therefore, folic acid may be used as a novel treatment for prevention of orthostatic deregulation and/or arrhythmic complications resulting from baroreceptor dysfunction. ${ }^{39} \mathrm{~A}$ report from a large study that included 7,373 young women and 12,347 older women suggested that a higher total amount (1000 $\mathrm{mcg} /$ day) of dietary folate intake and folic acid supplementation in younger women compared with consumption of less than $200 \mathrm{mcg} /$ day was associated with a reduced risk of hypertension. ${ }^{40}$

\section{Stroke}

Yang et al. suggested that there might be a potential benefit of stroke prevention with folic acid supplementation. ${ }^{41}$ Wang et al. in a meta-analyses concluded that there was a significant reduction in the risk of stroke by $18 \%$ with folic acid supplementation and it was more beneficial in those i) with more than 36 months of treatment, ii) with a $20 \%$ or more reduction of homocysteine level, iii) with minimal or no fortification of grain in their diet, iv) with no history of stroke. Wang et al. therefore indicated in their findings that the risk of stroke was reduced with folic acid supplementation. ${ }^{42}$ Similarly, Huo et al. indicated that in an effort to prevent stroke, folic acid supplementation was effective in statins consumption free populations and in those with partial or without folic acid fortification. ${ }^{43}$ Lee at al. suggested that the combination of folate and $\mathrm{B}$ vitamins in male patients has a potential benefit in the primary prevention of stroke. ${ }^{44}$

\section{Diabetes}

Folic acid supplementation in patient with type 2 diabetes mellitus was seen to cause reduction in homocysteine levels and, therefore, contributed to better glycemic control. ${ }^{45}$ Diabetes is associated with endothelial dysfunction due to the uncoupling of endothelial nitric oxide (NO) synthase enzyme. Title et al. reported in a study on type 2 diabetes mellitus patients who were treated with folic acid $(10 \mathrm{mg} /$ day for 2 weeks) versus placebo that folic acid supplementation improved endothelial dysfunction and was found to significantly improve fasting endothelium-dependent flow-mediated dilatation (FMD). However, no effects were seen on lipid profiles, endotheliumindependent nitroglycerin-mediated dilatation (NMD) or inflammatory markers. ${ }^{46} \mathrm{Xu}$ et al. reported that supplementation with folic acid and vitamin B12 had the effect of protecting the capillaries of the kidney from damage, and the mechanism may have something to do with the effect of anti-oxygenation. ${ }^{47}$ On the contrary, Schneider et al. conducted a randomized trial and reported that high-dose folic acid treatment did not improve renal endothelial function and failed to reduce albuminuria in human subjects with diabetic nephropathy. ${ }^{48}$ Raised serum homocysteine concentration levels due to reduction of folic acid and vitamin B12 levels increased the risk of diabetic retinopathy. ${ }^{49}$ Likewise, folic acid was shown to protect diabetic rats against diabetic peripheral neuropathy and the reason may be related to the improvement of the expression of nerve growth factor levels. ${ }^{50}$ The combination of uridine monophosphate, folic acid and vitamin B12 was also shown to improve neuropathic pain in diabetic neuropathy. ${ }^{51}$ There was a reported finding that suggested a greater risk of spina bifida in babies of pregnant mothers who were diabetic and had lower folic acid intake. $^{52}$

\section{Pregnancy}

During the pre-conception period, risks of stillbirths secondary to neural tube defects (NTDs) were reduced with folic acid supplementation by approximately $41 \%{ }^{53}$ It was suggested therefore, for public benefit and significant reduction of the risk of recurrent NTDs, that targeted folic acid counseling should be given to women with a previous pregnancy affected by NTDs. ${ }^{54}$ Likewise, it was suggested for folic acid-preventable NTDs that the implementation of targeted, innovative, education campaigns and fortification of ethnic minority foods, especially in non-Caucasian communities that consumed less folic acid during the pre-conception period compared to Caucasians in the United Kingdom, will be required. ${ }^{55}$ There were many controversies on the continuous supplementation of folic acid during the second and third trimesters of pregnancy in the prevention of NTDs, un- 
like the well-recognized beneficial effects of its supplementation before and shortly after conception. Charles et al. found folic acid supplementation when given from time of initial antenatal appointment onwards to be of no benefit and no difference in birth and placental weight or gestational age of the pregnancy was observed, contrary to the Cochrane review, which reported that high doses of folic acid supplementation could reduce the risk of low birth weight. ${ }^{56}$ Similarly, Fekete et al. reported no beneficial effect of folic acid supplementation on either the weight of the placenta or on gestational length. However, when doubling folate intake, there was an observed $2 \%$ increase in birth weight. Therefore it was suggested that more research studying the effect of folate supplementation in pregnancy would be necessary and useful in order to develop further guidelines and recommendations for pregnant women. ${ }^{57,58}$ Wien et al. reported no statistically significant evidence of any beneficial effects of folic acid supplementations on other birth defects other than NTDs. ${ }^{59,60}$ Although Lassi et al. reported a significant reduction in the incidence of megaloblastic anemia in those with folic acid supplementation, the review did not find folic acid to have any impact on the improvement of other hematological indices, such as antenatal anemia, mean pre-delivery hemoglobin level, mean predelivery serum folate levels and mean pre-delivery red cell folate levels. $^{57}$

\section{Cancer}

Volsett et al. reported that folic acid supplementations did not alter the incidences of cancer in any other specific site nor did it in the first 5 years of cancer treatment reduce the chances of relapse of cancer. ${ }^{61}$ Likewise, Qin et al. concluded that besides melanoma, cancer incidences of colorectal carcinoma, prostate, lung, breast or hematological malignancies were not reduced by folic acid supplementation. ${ }^{62}$ Baggott et al. in their analysis suggested that cancer incidences were higher in those with folic acid consumption than in those without folic acid consumption. It was therefore suggested that due to contradictory findings on this issue, prior to the commencement of folic acid supplementation studies and trials, evidences of side effects of cancer recurrence with this supplementation should first be made known. ${ }^{63}$

\section{Prostate cancer}

Wien et al. explored the risk of prostate cancer and oral supplementation of folic acid in the supplemented groups compared to controls. The incidence of prostate cancer was found to have increased but there were no reported increases in cancer mortality. It was suggested that future studies, especially prospective studies, should investigate whether food fortification similar to folic acid supplementation increases the risk of prostate cancer. ${ }^{64}$ However, the association of prostate cancer risk and the supplementation of folate and vitamin B12 on the genetic polymorphism associated with folate-pathway yielded many contradictory findings. Collin et al. reported in a meta-analysis that increased risk of prostate cancer was associated with a high concentration of vitamin B12 and folate. However the reversed was seen with high homocysteine levels. Regarding folate-pathway polymorphisms, only the MTR 2756A > G and SHMT1 1420C > T polymorphisms were positively associated with prostate cancer risk. The high prevalence of prostate cancer in the population and increasing concerns over folic acid fortification presenting probable potential harms warrants investigations, as it has a significant public health outcome. ${ }^{65} \mathrm{~A}$ review reported that there were many evidences that higher circulating folate levels can contribute to prostate cancer progression. ${ }^{66}$ However, a more recent report showed that no association was found between the progression of prostate cancer risk and continued consumption of folic acid post treatment. ${ }^{67}$ Interestingly, a meta-analysis reported that dietary and total folate intake did not contribute significantly to the risk of prostate cancer but consistently high blood folate levels were associated with an increased risk of prostate cancer. ${ }^{68}$

\section{Colorectal cancer}

There have been many contradictory reports on the association between folic acid and colorectal carcinoma. Earlier reports in the 1990s showed that low folate levels predisposed to the development of adenomas but folate supplementation did not reduce the relapse rate at 2 years. ${ }^{69,70}$ Folic acid has been identified as a foreseeable mean of chemoprevention of colorectal cancer, but Carroll et al. reported in a systematic review on various populations that folic acid has not been shown to be effective in the chemoprevention of colorectal adenomas or cancer. ${ }^{71}$ Figueiredo et al. suggested that the risk of colorectal cancer is increased with lower folate level, therefore folate could be chemoprotective. However, no history of increased or decreased adenoma occurrence after up to 3.5 years of folic acid were observed. ${ }^{72}$ Similarly, CastilloLancellotti et al. reported that folic acid supplementation was not beneficial in relapses of colorectal adenomas. The risk of cancer have been observed in some studies to differ with the levels of supplementation of folate; therefore, in populations with higher risks, the criteria for supple- 
mentations might need to be reviewed and revised..$^{73}$ Interestingly, Keum and Giovannucci reported that the increase in colorectal cancer incidence rates in the United States in the later 1990s were unlikely due to folic acid fortification and folate appears to be one of the most promising factors that could explain the downward trend of current colorectal incidence rates. ${ }^{74}$ These data helped to reassure women planning a pregnancy to start folic acid intake sufficient to prevent neural tube defects prior to conception. ${ }^{75}$ Heavy alcohol consumption was postulated to increase the risk for colorectal cancer due to the increased catabolism of methionine, as well as the depletion of mucosal folate due to alcohol metabolism to acetaldehyde from the colonic flora. ${ }^{76,77}$ Plasma folate concentration was also reported to be positively associated with colorectal cancer risk among men who may have had pre-neoplastic lesions. ${ }^{78}$

\section{Pancreatic cancer}

Inconsistent results have been reported on the association between the risk of pancreatic cancer and folate intake as these studies were mostly small in sample sizes and reported on variable ranges of folate intake. Bao et al. concluded from a large pooled analysis that there was no increased risk of pancreatic cancer with folate supplementation. ${ }^{79}$ Similarly, Oaks et al. also reported that folic acid supplementation was not associated with pancreatic cancer. Pancreatic cancer risk was reduced in women with better food folate consumption compared to men. ${ }^{80}$ The same was observed by Skinner et al. in two large prospective cohort studies. ${ }^{81}$ Dietary folate was also reported to be protective against pancreatic cancer. ${ }^{82}$ However, Keszei et al. reported from findings of the Netherlands Cohort Study that the risk of pancreatic cancer was only weakly associated with folate intake $e^{83}$ and was inversely correlated with dietary folate intake. ${ }^{84,85}$

\section{Breast cancer}

Inconclusive findings were also reported on the relationship between breast cancer risk and folate supplementation or serum folate levels. However, it was reported that moderate or high alcohol consumption may increase the risk of breast cancer which may be reduced with adequate folate supplementation. ${ }^{86-88}$ Zhang et al. revealed that a daily folate intake of 200-320 $\mu$ g appeared to be associated with a lower risk of breast cancer, and increased breast cancer risk was associated with a daily folate intake $>400 \mu \mathrm{g} /$ day.${ }^{89}$ However, the latest data by Deghan et al. on a study conducted on female Sprague-Dawley rats suggested that folic acid supplementation in doses of 2.5 to five times of the daily requirement may promote the progression of existing pre-cancerous or cancerous cells in the mammary glands. ${ }^{90}$

\section{Childhood leukemia}

The supplementation of folic acid prior to conception may reduce the risk of childhood leukemia. ${ }^{91}$ Lupo et al. reported that folic acid supplementation did not have any association with the risk of Acute Lymphoblastic Leukemia (ALL) in children..$^{92}$ There was no significant difference in level of folate reported in the survivors of childhood acute lymphoblastic leukemia with or without neuropathy. ${ }^{93}$

\section{Lung cancer}

Lung cancer risk could be reduced with a higher folate intake. ${ }^{94}$ Shen et al. suggested that there was a possible protective role of dietary folate in lung cancer. ${ }^{95}$ The inverse relationship between the risk of lung cancer and folate supplementation was also reported in an earlier research. ${ }^{96}$ Long term use of folic acid was also not reported to be beneficial to prevent lung cancer. ${ }^{97}$ The study in the South Pacific, amongst the New Caledonian men suggested that the risk of lung cancer may be reduced with a high consumption of dark green leafy vegetables. ${ }^{98}$ Likewise, Neuhouser et al. similarly reported that plant food may be preventative for lung cancer in a population at higher risk but both these studies were not folate-specific. ${ }^{99}$ As for lung cancer treatment, Pemetrexed (MTA) is a multi-targeted anti-folate drug approved for lung cancer therapy and it was reported that the supplementation of folic acid resulted in better survival in MTA-treated patients. ${ }^{100}$

\section{Kidney diseases}

Folic acid supplementation may be effective for the prevention of cardiovascular disease (CVD) in patients with kidney disease without previous consumption of grain fortification with folic acid, diabetics and in those with end stage renal disease (ESRD). ${ }^{101}$ Qin et al. also reported the benefit of folic acid supplementation on the reduction of CVD risk in patients with ESRD by $15 \%$. In those with partial or no folic acid fortification and in those with a decrease in Hcy level > 20\%, the beneficial effect was seen to be greater. ${ }^{102}$ On the contrary, Jardine et al. reported that in those on folic acid-based homocysteine lowering regime with kidney disease, no reduction in the cardiovascular events was seen. ${ }^{103}$

\section{Neurology}

The use of folic acid supplementation for the prevention of Alzheimer's disease and cognitive decline had been dis- 
cussed and debated in recent years. Schneider et al. reported contradictory results on the use of folic acid supplements in the effort to prevent cognitive decline. A few studies suggested that folic acid supplementation in those with folate deficiencies may provide neuroprotection, however, risk to neurological function was also seen in those without folate deficiencies. ${ }^{104}$ Despite earlier reports on the benefits of folate and vitamin B complex in the maintenance of cognitive function, Castillo et al. reported that folic acid supplementation was not beneficial for cognitive function in the elderly. Low folate serum levels may lead to cognitive impairment and the combination of high levels of folic acid and low levels of vitamin B12 may lead to further deterioration. Therefore, it was suggested that fortification of food with folic acid should be re-examined to maximize benefits and to limit potential risks. ${ }^{105}$

\section{Childhood asthma}

The high morbidity and increasing prevalence of childhood asthma has made it a critical public health problem in recent years, therefore interest into research on the impact of nutrition and other exposures during pregnancy on this issue has increased. A study suggested that supplementation of high-dose folic acid during pregnancy might increase the risk of childhood asthma. ${ }^{106}$ Crider et al. however reported in a meta-analysis that there were no evidences of the association between maternal folic acid supplement use (compared with no use) in the prepregnancy period through the first trimester and risk of asthma in childhood. However, additional research in this area is needed because of the limited number and types of studies found in the literature. ${ }^{107}$

\section{Conclusion}

The increasing pool of evidence supporting the healthpromoting effects of folic acid suggests the possibility of its future role in the prevention and the treatment of diseases. Folic acid is used as a supplement in most cases but is increasingly being used as medication especially in trials as an anti-cancer medication. Although the effect of folic acid supplementation during the pre-conception period to reduce the incidence of neural tube defects (NTDs) is well established, its effect on other diseases yielded many contradictory results. Therefore, research into its effect on these diseases warrant further investigations. Most of the published studies were observational studies and a lesser proportion was conducted on cell lines and animals. Supplementation and medicinal benefits of folic acid in some diseases should only be recommended when its beneficial effects are well established in humans.

\section{ACKNOWLEDGEMENT}

The author would like to thank Sheba D. Mani from the Language Department of the International Medical University for the language editing of this manuscript.

\section{Resumo}

Ácido fólico e doenças - suplementá-lo ou não?

Introdução: ácido fólico é uma vitamina solúvel em água produzida sinteticamente e encontrada em alimentos e suplementos enriquecidos. O folato é encontrado naturalmente em plantas, como vegetais folhosos verde-escuros. O folato não é sintetizado de novo por seres humanos; portanto, as necessidades diárias são satisfeitas a partir da ingestão de suplementos de ácido fólico ou alimentos ricos nessa vitamina. A deficiência de folato pode levar a inúmeros problemas de saúde comuns. Hiper-homocisteinemia e a possibilidade de desenvolver malignidades são as consequências a longo prazo desse déficit, ainda que os resultados sejam contraditórios sobre essas afirmações.

Métodos: os artigos incluídos nesta revisão tratam de relatórios recentes atualizados com base em provas e metanálises sobre a associação entre o folato/ácido fólico e várias doenças encontradas globalmente.

Resultados: o benefício da suplementação de ácido fólico no período de pré-concepção para a prevenção de defeitos do tubo neural (DTN) foi bem estabelecido e foi sugerido que sessões de aconselhamento devem ser providas às mulheres com gravidezes anteriores afetadas por DTN. No entanto, os benefícios da suplementação de ácido fólico e os efeitos medicinais no tratamento de outras doenças são contraditórios e pouco claros.

Conclusão: investigações mais detalhadas sobre os benefícios do ácido fólico são necessárias antes que a suplementação seja recomendada para tratamento ou prevenção de algumas das doenças discutidas nesta revisão.

Palavras-chave: ácido fólico, homocisteína, classificação de doenças, suplementos dietéticos.

\section{References}

1. Dietary supplement fact sheet. Folate. Health Information. Office of Dietary Supplements, US National Institutes of Health; 2014. Available from: http://ods.od.nih.gov/factsheets/Folate-HealthProfessional.

2. Weinstein SJ, Hartman TJ, Stolzenberg-Solomon R, Pietinen P, Barrett MJ, Taylor PR, et al. Null association between prostate cancer and serum folate, vitamin $\mathrm{B}(6)$, vitamin $\mathrm{B}(12)$, and homocysteine. Cancer Epidemiol Biomarkers Prev. 2003; 12 (11 Pt 1):1271-2. 
3. Botez MI. Folate deficiency and neurological disorders in adults. Med Hypotheses. 1976; 2(4):135-40.

4. Pubchem; 2014. Available from: https://pubchem.ncbi.nlm.nih.gov/.

5. Hoffbrand AV, Weir DG. The history of folic acid. Br J Haem. 2001; 113(3):579-89.

6. Wills L. Treatment of "pernicious anaemia of pregnancy" and "tropical anaemia" with special reference to yeast extract as curative agent. Brit Med J. 1931; 1(3676):1059-64

7. Mitchell HK, Snell EE, Williams RJ. The concentration of folic acid. J Amer Chem Soc. 1941; 63:2284.

8. Angier RB, Boothe JH, Hutchings BL, Mowat JH, Semb J, Stokstad EIR, et al. Synthesis of a compound identical with the $\mathrm{L}$. casei factor isolated from liver. Science. 1945; 102(2644):227-8.

9. Hanes EM. Diagnostic criteria and resistance to therapy in the sprue syndrome. Am J Med Sci. 1942; 204(3):436-43

10. Davidson LSP, Girdwood RH, Innes EM. Folic acid in the treatment of sprue syndrome. Lancet. 1947; i:511-15.

11. Canadian Nutrient File (Dietitician of Canada); 2010. Available from: www hc-sc.gc.ca/fn-an/nutrition/fiche-nutri-data/index-eng.php.

12. Carmel R. Folic acid. In: Shils M, Shike M, Ross A, Caballero B, Cousins R Modern nutrition in health and disease. Baltimore: Lippincott Williams \& Wilkins, 2005. p.470-81.

13. Institute of Medicine Food and Nutrition Board. Dietary reference intakes: thiamin, riboflavin, niacin, vitamin B6, folate, vitamin B12, pantothenic acid, biotin, and choline. Washington, DC: National Academy Press, 1998

14. Bailey LB, Gregory JF 3rd. Folate. In: Bowman B, Russell R (eds.). Present Knowledge in Nutrition. Washington DC: International Life Sciences Institute, 2006. p.278-301.

15. Yetley EA, Pfeiffer CM, Phinney KW, Yetley EA, Pfeiffer CM, Phinney KW, et al. Biomarkers of folate status in NHANES: a roundtable summary. Am J Clin Nutr. 2011; 94(1):303S-12S

16. Green R. Indicators for assessing folate and vitamin B-12 status and for monitoring the efficacy of intervention strategies. Am J Clin Nutr. 2011; 94(2):666S-72S

17. Duthie S. Folic acid deficiency and cancer: mechanisms of DNA instability. Br Med Bull. 1999; 55(3):578-92.

18. Lindhahl T, Ljungquist S, Siegert W, Nyberg B, Sperens B. DNA N-glycosidases: properties of uracil-DNA glycosidase from Escherichia coli. J Biol Chem. 1977; 252(10):3286-94.

19. Goulian M, Bleile B, Tseng B. Methotrexate-induced misincorporation of uracil in DNA. Proc Natl Acad Sci USA. 1980; 77(4):1956-60.

20. Reidy JA. Folate and deoxyuridine sensitive chromatid breakage may result from DNA repair during G2. Mutat Res. 1987; 192(3):217-9.

21. Reidy JA. Role of deoxyuridine incorporation and DNA repair in the expression of human chromosomal fragile sites. Mutat Res. 1988; 200(1-2):215-20.

22. Fang JY, Zhu SS, Xiao SD, Jiang SJ, Shi Y, Chen XY, et al. Studies on the hypomethylation of c-myc, cHa-ras oncogenes and histopathological changes in human gastric carcinoma. J Gastroenterol Hepatol.1996; 11:1079-82.

23. Feinberg AP, Volgelstein B. Hypomethylation distinguishes genes of some human cancers from their normal counterparts. Nature. 1983; 301:89-92.

24. Ghoshal AK, Farber E. The induction of liver cancer by dietary deficiency of choline and methionine without added carcinogens. Cancer Res. 1984; $5(10): 1367-70$.

25. Jacques PF, Bostom AG, Williams RR, Ellison RC, Eckfeldt JH, Rosenberg $\mathrm{IH}$, et al. Relation between folate status, a common mutation in methylenetetrahydrofolate reductase, and plasma homocysteine concentrations. Circulation. 1996; 93(1):7-9.

26. Rozen R. Genetic predisposition to hyperhomocysteinemia: deficiency of methylenetetrahydrofolate reductase (MTHFR). Thromb Haemost. 1997; 78(1):523-6.

27. Stanger O, Herrman W, Pietrzik K, Fowler B, Giesel J, Dierkes J, et al. Clinical use and rational management of homocysteine, folic acid, and $\mathrm{B}$ vitamins in cardiovascular and thrombotic diseases. Z Kardiol. 2004 93(6):439-53.

28. Welsch G, Upchurch G, Loscalzo J. Hyperhomocysteinaemia and atherothrombosis. Ann NY Acad Sci. 1997; 811:48-58.

29. Homocysteine Lowering Trialists' Collaboration. Dose-dependent effects of folic acid on blood concentrations of homocysteine: a meta-analysis of the randomized trials. Am J Clin Nutr. 2005; 82(4):806-12.

30. Homocysteine Lowering Trialists' Collaboration. Lowering blood homocysteine with folic acid based supplements: meta-analysis of randomised trials. BMJ. 1998; 316:894-8.
31. Qin X, Xu M, Zhang Y, Li J, Xu X, Wang X, et al. Effect of folic acid supplementation on the progression of carotid intima-media thickness: a meta-analysis of randomized controlled trials. Atherosclerosis. 2012; 222(2):307-13.

32. Wang ZM, Zhou B, Nie ZL, Gao W, Wang YS, Zhao H, et al. Folate and risk of coronary heart disease: a meta-analysis of prospective studies. Nutr Metab Cardiovasc Dis. 2012; 22(10):890-9.

33. de Bree A, van Mierlo LA, Draijer R. Folic acid improves vascular reactivity in humans: a meta-analysis of randomized controlled trials. Am J Clin Nutr. 2007; 86(3):610-7.

34. Miller ER 3rd, Juraschek S, Pastor-Barriuso R, Bazzano LA, Appel LJ, Guallar E. Meta-analysis of folic acid supplementation trials on risk of cardiovascular disease and risk interaction with baseline homocysteine levels. Am J Cardiol. 2010; 106(4):517-27.

35. Zhou YH, Tang JY, Wu MJ, Lu J, Wei X, Qin YY, et al. Effect of folic acid supplementation on cardiovascular outcomes: a systematic review and metaanalysis. PLoS One. 2011; 6(9):e25142.

36. Bazzano LA, Reynolds K, Holder KN, He J. Effect of folic acid supplementation on risk of cardiovascular diseases: a meta-analysis of randomized controlled trials. JAMA. 2006; 296(22):2720-6.

37. McRae MP. High-dose folic acid supplementation effects on endothelial function and blood pressure in hypertensive patients: a meta-analysis of randomized controlled clinical trials. J Chiropr Med. 2009; 8(1):15-24

38. Cagnacci A, Cannoletta M, Xholli A, Piacenti I, Palma F, Palmieri B. Folate administration decreases oxidative status and blood pressure in postmenopausal women. Eur J Nutr. 2015; 54(3):429-35.

39. Béchir M, Enseleit F, Chenevard R, Muntwyler J, Lüscher TF, Noll G. Folic Acid improves baroreceptor sensitivity in hypertension. J Cardiovasc Phar macol. 2005; 45(1):44-8.

40. Forman JP, Rimm EB, Stampfer MJ, Curhan GC. Folate intake and the risk of incident hypertension among US women. JAMA. 2005; 293(3):320-9.

41. Yang HT, Lee M, Hong KS, Ovbiagele B, Saver JL. Efficacy of folic acid supplementation in cardiovascular disease prevention: an updated meta-analysis of randomized controlled trials. Eur J Intern Med. 2012; 23(8):745-54

42. Wang X, Qin X, Demirtas H, Li J, Mao G, Huo Y, et al. Efficacy of folic acid supplementation in stroke prevention: a meta-analysis. Lancet. 2007; 369(9576):1876-82

43. Huo Y, Qin X, Wang J, Sun N, Zeng Q, Xu X, et al. Efficacy of folic acid supplementation in stroke prevention: new insight from a meta-analysis. Int $J$ Clin Pract. 2012; 66(6):544-51.

44. Lee M, Hong KS, Chang SC, Saver JL. Efficacy of homocysteine-lowering therapy with folic acid in stroke prevention: a meta-analysis. Stroke. 2010; 41(6): $1205-12$.

45. Sudchada P, Saokaew S, Sridetch S, Incampa S, Jaiyen S, Khaithong W. Effect of folic acid supplementation on plasma total homocysteine levels and glycemic control in patients with type 2 diabetes: a systematic review and meta-analysis. Diabetes Res Clin Pract. 2012; 98(1):151-8.

46. Title LM, Ur E, Giddens K, McQueen MJ, Nassar BA. Folic acid improves endothelial dysfunction in type 2 diabetes--an effect independent of homocysteine-lowering. Vasc Med. 2006; 11(2):101-9.

47. Xu R, Fan Y, Xiang J, Zhan M. Effect of the folic acid and vitamin B2 on the diabetes mellitus rats with diabetic nephropathy. Wei Sheng Yan Jiu. 2012; 41(6):911-5.

48. Schneider MP, Schneider A, Jumar A, Kistner I, Ott C, Schmieder RE. Effects of folic acid on renal endothelial function in patients with diabetic nephropathy: results from a randomized trial. Clin Sci (Lond). 2014; 127(7):499505.

49. Fotiou P, Raptis A, Apergis G, Dimitriadis G, Vergados I, Theodossiadis P. Vitamin status as a determinant of serum homocysteine concentration in type 2 diabetic retinopathy. J Diabetes Res. 2014; 2014:807209.

50. Yilmaz M, Aktug H, Oltulu F, Erbas O. Neuroprotective effects of folic acid on experimental diabetic peripheral neuropathy. Toxicol Ind Health. 2013 [Epub ahead of print]

51. Negrão L, Almeida P, Alcino S, Duro H, Libório T, Silva U, et al. Effect of the combination of uridine nucleotides, folic acid and vitamin B12 on the clinical expression of peripheral neuropathies. Pain Management. 2014; 4(3):191-6.

52. Parker SE, Yazdy MM, Tinker SC, Mitchell AA, Werler MM. The impact of folic acid intake on the association among diabetes mellitus, obesity, and spina bifida. Am J Obstet Gynecol. 2013; 209(3):239.e1-8

53. Imdad A, Yakoob MY, Bhutta ZA. The effect of folic acid, protein energy and multiple micronutrient supplements in pregnancy on stillbirths. BMC Public Health. 2011; 11 Suppl 3:S4. 
54. Grosse SD, Collins JS. Folic acid supplementation and neural tube defect recurrence prevention. Birth Defects Res A Clin Mol Teratol. 2007; 79(11):737-42.

55. Peake JN, Copp AJ, Shawe J. Knowledge and periconceptional use of folic acid for the prevention of neural tube defects in ethnic communities in the United Kingdom: systematic review and meta-analysis. Birth Defects Res A Clin Mol Teratol. 2013; 97(7):444-51.

56. Charles DH, Ness AR, Campbell D, Smith GD, Whitley E, Hall MH. Folic acid supplements in pregnancy and birth outcome: re-analysis of a large randomised controlled trial and update of Cochrane review. Paediatr Perinat Epidemiol. 2005; 19(2):112-24.

57. Lassi ZS, Salam RA, Haider BA, Bhutta ZA. Folic acid supplementation during pregnancy for maternal health and pregnancy outcomes. Cochrane Database Syst Rev. 2013; 3:CD006896.

58. Fekete K, Berti C, Trovato M, Lohner S, Dullemeijer C, Souverein OW, et al. Effect of folate intake on health outcomes in pregnancy: a systematic review and meta-analysis on birth weight, placental weight and length of gestation. Nutr J. 2012; 11:75.

59. De-Regil LM, Fernández-Gaxiola AC, Dowswell T, Peña-Rosas JP. Effects and safety of periconceptional folate supplementation for preventing birth defects. Cochrane Database Syst Rev. 2010; 6:CD007950.

60. Jian M, Wang J, Sun H. Meta-analysis of effect of intervention with folic acid on neural tube defects. Wei Sheng Yan Jiu. 2009; 38(6):682-4.

61. Vollset SE, Clarke R, Lewington S, Ebbing M, Halsey J, Lonn E, et al. Effects of folic acid supplementation on overall and site-specific cancer incidence during the randomised trials: meta-analyses of data on 50,000 individuals Lancet. 2013; 381(9871):1029-36.

62. Qin X, Cui Y, Shen L, Sun N, Zhang Y, Li J, et al. Folic acid supplementation and cancer risk: a meta-analysis of randomized controlled trials. Int J Cancer. 2013; 133(5):1033-41.

63. Baggott JE, Oster RA, Tamura T. Meta-analysis of cancer risk in folic acid supplementation trials. Cancer Epidemiol. 2012; 36(1):78-81.

64. Wien TN, Pike E, Wisløff T, Staff A, Smeland S, Klemp M. Cancer risk with folic acid supplements: a systematic review and meta-analysis. BMJ Open. 2012; 2(1):e000653.

65. Collin SM. Folate and B12 in prostate cancer. Adv Clin Chem. 2013; 60:1-63.

66. Rycyna KJ, Bacich DJ, O'Keefe DS. Opposing roles of folate in prostate cancer. Urology. 2013; 82(6):1197-203.

67. Tomaszewskia J, Richmanc E, Sadetskyd N, O'Keefea D, Carrolld P, Daviesb $\mathrm{B}$, et al. Impact of folate intake on prostate cancer recurrence following definitive therapy: data from CaPSURE. J Urol. 2014; 191(4):971-6.

68. Tio M, Andrici J, Cox MR, Eslick GD. Folate intake and the risk of prostate cancer: a systematic review and meta-analysis. Prostate Cancer Prostatic Dis 2014; 17(3):213-9.

69. Paspatis GA, Kalafatis E, Oros L, Xourgias V, Koutsioumpa P, Karamanolis DG. Folate status and adenomatous colonic polyps. A colonoscopically controlled study. Dis Colon Rectum. 1995; 38(1):64-7.

70. Paspatis G, Karamanolis D. Folate supplementation and adenomatous colonic polyps. Dis Colon Rectum. 1994; 37(12):1340-1.

71. Carroll C, Cooper K, Papaioannou D, Hind D, Tappenden P, Pilgrim H, et al. Meta-analysis: folic acid in the chemoprevention of colorectal adenomas and colorectal cancer. Aliment Pharmacol Ther. 2010; 31(7):708-18.

72. Figueiredo JC, Mott LA, Giovannucci E, Wu K, Cole B, Grainge MJ, et al. Folic acid and prevention of colorectal adenomas: a combined analysis of randomized clinical trials. Int J Cancer. 2011; 129(1):192-203.

73. Castillo-Lancellotti C, Tur Marí JA, Uauy Dagach R. Folic acid supplementation and colorectal adenoma recurrence: systematic review. Nutr Hosp. 2012; 27(1):13-21.

74. Keum N, Giovannucci EL. Folic acid fortification and colorectal cancer risk Am J Prev Med. 2014; 46(3):S65-72.

75. Kennedy DA, Stern SJ, Moretti M, Matok I, Sarkar M, Nickel C, et al. Folate intake and the risk of colorectal cancer: a systematic review and meta-analysis. Cancer Epidemiol. 2011; 35(1):2-10.

76. Ryan BM, Weir DG. Relevance of folate metabolism in the pathogenesis of colorectal cancer. J Lab Clin Med. 2001; 138(3):164-76.

77. Giovannucci E, Rimm EB, Ascerio A, Stampfer MJ, Colditz GA, Willett WC Alcohol, low-methionine-low- folate diets and risk of colon cancer in men. J Natl Cancer Inst. 1995; 87(4):265-73.

78. Takata Y, Shrubsole MJ, Li H, Cai Q, Gao J, Wagner C, et al. Plasma folate concentrations and colorectal cancer risk: A case-control study nested within the Shanghai Men's Health Study. Int J Cancer. 2014; 135(9):2191-8.
79. Bao Y, Michaud DS, Spiegelman D, Albanes D, Anderson KE, Bernstein L, et al. Folate intake and risk of pancreatic cancer: pooled analysis of prospective cohort studies. J Natl Cancer Inst. 2011; 103(24):1840-50.

80. Oaks BM, Dodd KW, Meinhold CL, Jiao L, Church TR, Stolzenberg-Solomon RZ. Folate intake, post-folic acid grain fortification, and pancreatic cancer risk in the Prostate, Lung, Colorectal, and Ovarian Cancer Screening Trial. Am J Clin Nutr. 2010; 91(2):449-55.

81. Skinner H, Michaud D, Giovannucci E, Rimm E, Stampfer M, Willett W, et al. A prospective study of folate intake and the risk of pancreatic cancer in men and women. Am J Epidemiol. 2004; 160(3):248-58.

82. Lin HL, An QZ, Wang QZ, Liu CX. Folate intake and pancreatic cancer risk: an overall and dose-response meta-analysis. Public Health. 2013; 127(7):607-13.

83. Keszei AP, Verhage BA, Heinen MM, Goldbohm RA, van den Brandt PA. Dietary folate and folate vitamers and the risk of pancreatic cancer in the Netherlands cohort study. Cancer Epidemiol Biomarkers Prev. 2009; 18(6):1785-91.

84. Stolzenberg-Solomon RZ, Pietinen P, Barrett MJ, Taylor PR, Virtamo J, Albanes D. Dietary and other methyl-group availability factors and pancreatic cancer risk in a cohort of male smokers. Am J Epidemiol. 2001; 153(7):680-7.

85. Larsson SC, Håkansson N, Giovannucci E, Wolk A. Folate intake and pancreatic cancer incidence: a prospective study of Swedish women and men. J Natl Cancer Inst. 2006; 98(6):407-13.

86. Larsson SC, Giovannucci E, Wolk A. Folate and risk of breast cancer: a meta-analysis. J Natl Cancer Inst. 2007; 99:64-76.

87. Stolzenberg-Solomon RZ, Chang SC, Leitzmann MF, Johnson KA, Johnson C, Buys SS, et al. Folate intake, alcohol use, and postmenopausal breast cancer risk in the Prostate, Lung, Colorectal, and Ovarian Cancer Screening Trial. Am J Clin Nutr. 2006; 83(4):895-904.

88. Chen $\mathrm{P}, \mathrm{Li} \mathrm{C}, \mathrm{Li} \mathrm{X}, \mathrm{Li}$ J, Chu R, Wang $\mathrm{H}$. Higher dietary folate intake reduces the breast cancer risk: a systematic review and meta-analysis. Brit J Cancer. 2014; 110(9):2327-38.

89. Zhang YF, Shi WW, Gao HF, Zhou L, Hou AJ, Zhou YH. Folate intake and the risk of breast cancer: a dose-response meta-analysis of prospective studies. PLoS One. 2014; 9(6):e100044.

90. Deghan Manshadi S, Ishiguro L, Sohn KJ, Medline A, Renlund R, Croxford $\mathrm{R}$, et al. Folic acid supplementation promotes mammary tumor progression in a rat model. PLoS One. 2014; 9(1):e84635.

91. Ajrouche R, Rudant J, Orsi L, Petit A, Baruchel A, Nelken B, et al. Maternal reproductive history, fertility treatments and folic acid supplementation in the risk of childhood acute leukemia: the ESTELLE Study. Cancer Causes Control. 2014; 25(10):1283-93.

92. Lupo PJ, Dietz DJ, Kamdar KY, Scheurer ME. Gene-environment interac tions and the risk of childhood acute lymphoblastic leukemia: exploring the role of maternal folate genes and folic acid fortification. Pediatr Hematol Oncol. 2014; 31(2):160-8.

93. Jain P, Gulati S, Toteja GS, Bakhshi S, Seth R, Pandey RM. Serum alpha tocopherol, vitamin B12, and folate levels in childhood acute lymphoblastic leukemia survivors with and without neuropathy. J Child Neurol. 2015; 30(6):786-8.

94. Dai WM, Yang B, Chu XY, Wang YQ, Zhao M, Chen L, et al. Association between folate intake, serum folate levels and the risk of lung cancer: a systematic review and meta-analysis. Chin Med J. 2013; 126(10):1957-64.

95. Shen H, Wei Q, Pillow PC, Amos CI, Hong WK, Spitz MR. Dietary folate intake and lung cancer risk in former smokers: a case-control analysis. Cancer Epidemiol Biomarkers Prev. 2003; 12(10):980-6.

96. Bandera EV, Freudenheim JL, Marshall JR, Zielezny M, Priore RL, Brasure J, et al. Diet and alcohol consumption and lung cancer risk in the New York State Cohort (United States). Cancer Causes Control. 1997; 8(6):828-40.

97. Slatore CG, Littman AJ, Au DH, Satia JA, White E. Long-term use of supplemental multivitamins, vitamin $\mathrm{C}$, vitamin $\mathrm{E}$, and folate does not reduce the risk of lung cancer. Am J Respir Crit Care Med. 2008; 177(5):524-30.

98. Marchand JL, Luce D, Goldberg P, Bugel I, Salomon C, Goldberg M. Dietary factors and the risk of lung cancer in New Caledonia (South Pacific). Nutr Cancer. 2002; 42(1):18-24.

99. Neuhouser ML, Patterson RE, Thornquist MD, Omenn GS, King IB, Goodman GE. Fruits and vegetables are associated with lower lung cancer risk only in the placebo arm of the beta-carotene and retinol efficacy trial (CARET). Cancer Epidemiol Biomarkers Prev. 2003; 12(4):350-8.

100. Yang TY, Chang GC, Hsu SL, Huang YR, Chiu LY, Sheu GT. Effect of folic acid and vitamin B12 on pemetrexed antifolate chemotherapy in nutrient lung cancer cells. Biomed Res Int. 2013; 2013:389046. 
101. Qin X, Huo Y, Xie D, Hou F, Xu X, Wang X. Homocysteine-lowering therapy with folic acid is effective in cardiovascular disease prevention in patients with kidney disease: A meta-analysis of randomized controlled trials. Clin Nutr.2013; 32(5):722-7.

102. Qin X, Huo Y, Langman CB, Hou F, Chen Y, Matossian D, et al. Folic acid therapy and cardiovascular disease in ESRD or advanced chronic kidney disease: a meta-analysis. Clin J Am Soc Nephrol. 2011; 6(3):482-8.

103. Jardine MJ, Kang A, Zoungas S, Navaneethan SD, Ninomiya T, Nigwekar SU, et al. The effect of folic acid based homocysteine lowering on cardiovascular events in people with kidney disease: systematic review and metaanalysis. BMJ. 2013; 344:e3533.
104. Schneider JA, Tangney CC, Morris MC. Folic acid and cognition in older persons. Expert Opin Drug Saf. 2006; 5(4):511-22.

105. Castillo Lancellotti C, Tur Marí JA, Uauy Dagach R. Effect of folate and related nutrients on cognitive function in older people; systematic review. Nutr Hosp. 2012; 27(1):90-102.

106. Zetstra-van der Woude P, De Walle H, Hoek A, Bos H, Boezen H, Koppelman $\mathrm{G}$, et al. Maternal high-dose folic acid during pregnancy and asthma medication in the offspring. Pharmacoepidemiol Drug Saf. 2014; 23(10):1059-65.

107. Crider KS, Cordero AM, Qi YP, Mulinare J, Dowling NF, Berry RJ. Prenatal folic acid and risk of asthma in children: a systematic review and meta-analysis. Am J Clin Nutr. 2013; 98:1272-81. 